Reprod. Nutr. Dévelop., 1985, 25 (5), 945-961.

\title{
Heterogeneity of adrenocorticotrophin in the pituitary gland and plasma during the perinatal period
}

\author{
J. P. DUPOUY, A. CHATELAIN
}

Laboratoire de Physiologie animale, Faculté des Sciences

33, rue Saint-Leu, 80039 Amiens Cedex

\section{Summary.}

1) Three immunoreactive forms of ACTH are characterized by their apparent molecular weight (MW) and bioactivity when acid extracts of the anterior or of the neurointermediate lobe of fetal and newborn rat pituitary glands are subjected to gel filtration on Sephadex G50 fine columns.

The "big " ACTH form which shows an apparent MW close to 44000 hardly stimulates the in vitro release of corticosterone by perifused fetal adrenals. In contrast, the " intermediate" (MW : $\simeq 13000)$ and "little " (MW: $\simeq 4500)$ forms show high biological activity by eliciting corticosterone secretion which is log-dose-dependent.

During the perinatal period, the relative proportions between these different molecular forms of ACTH change in both the anterior and neurointermediate lobes. "Big " ACTH is the main form in the neurointermediate lobe of the fetal rat pituitary. After birth, the "big " $\mathrm{ACTH} /$ total $\mathrm{ACTH}$ ratio regularly decreases until postpartum week 4 ; it is not very different then from that of pregnant adult females. The three immunoreactive forms of $\mathrm{ACTH}$ are present in the anterior lobe throughout the perinatal period. The gradual increase of the " intermediate " and "little " forms is accompanied by a correlative decrease in the "big" form.

2) The anterior lobes of 17, 19 and 21-day old fetuses, stimulated in vitro by an acid extract of adult hypothalamus, release the three immunoreactive forms of ACTH in the same proportions as those observed in corresponding extracts of anterior lobes.

3) On days 17, 19 and 21 of gestation, fetal plasma contains all the immunoreactive forms of ACTH previously observed in pituitary glands. The proportion of the "little " ACTH form gradually increases, whereas that of the "big " form decreases as gestation progresses. At term, the relative proportion of «little " ACTH is greater in the plasma than in the fetal pituitary.

4) Controlled trypsic digestion of pituitary " big " ACTH results in a conversion to the " intermediate" and "little " immunoreactive forms. When " intermediate " ACTH is submitted to tryptic digestion under the same conditions, there is continuous loss of immunoreactivity but no change of hormonal form. These findings strengthen the hypothesis that "big " ACTH is a precursor of " intermediate " and "little " ACTH ; in contrast, the "intermediate " form is not a precursor of the "little " one. The high molecular-weight form of ACTH might be converted endogenously into lower MW forms in the fetal circulation at term as well as in newborns.

5) In fetal plasma, immunoreactive ACTH levels reach peak values on day 19 of gestation and decrease thereafter until day 21. This profile of plasma ACTH levels could explain that of corticosterone concentration which also reaches a peak on day 19 in the adrenals as well as in the plasma. During the first postnatal days, the sharp decrease in 
plasma ACTH levels is in agreement with the low corticosterone concentrations reported in both the adrenals and the plasma of newborns.

During fetal life, the corticostimulatory activity of the pituitary gland is modulated both by the rate of ACTH release and by the biological potency of the different molecular forms of released $\mathrm{ACTH}$.

\section{Introduction}

Less than ten years ago, ACTH was still considered as a polypeptide hormone with 39 amino acid residues. The presence of other forms of ACTH was first reported in a cell line of mouse pituitary carcinoma (Orth et al., 1970, 1973). High molecular-weight immunoreactive ACTH was further observed in human plasma as well as in extracts of pituitary glands and ectopic tumors (Yalow and Berson, 1971). ACTH polymorphism was confirmed in the pituitary of several mammals, including man (Coslovsky and Yalow, 1974 ; Eipper and Mains, 1975 ; see review in Orth and Nicholson, 1977). Moreover, the high molecular-weight forms of ACTH were glycoproteins (Eipper et al., 1976). More recent studies on rat pituitary glands suggest that ACTH originates from a larger precursor molecule called ProACTH/endorphin (Eipper and Mains, 1978 ; Mains and Eipper, 1979) which also contains the amino acid sequences of both the $\beta \mathrm{LPH}$ and $16-\mathrm{K}$ fragments located near the $\mathrm{N}$-end of the precursor (Lowry et al., 1976 ; Eipper and Mains, 1978 ; Nakanishi et al., 1979).

While the polymorphism of ACTH has been investigated thoroughly over the last few years in both adult pituitary gland and plasma, few studies have examined the heterogeneity of ACTH in the fetus and newborn.

The aim of this paper is to review recent progress on the evolution of ACTH polymorphism in the pituitary gland and the plasma during perinatal development.

\section{ACTH polymorphism in the fetus and neonate}

A. ACTH in the pituitary gland. - The presence of the adrenocorticotrophic hormone (ACTH) in the neurointermediate and anterior lobes of the pituitary gland of fetal rats was demonstrated by using immunocytological (Chatelain et al., 1979), biological and radioimmunological (Chatelain and Dupouy, 1981 a, b) methods. The ACTH content of the fetal neurointermediate lobe from days 18 to 21 of gestation is 10 to 20 -fold less than that of the pars distalis (Chatelain and Dupouy, 1980a). Three forms of ACTH are characterized by their apparent molecular weight, bioactivity and immunoreactivity when acid extracts of whole fetal pituitary gland are subjected to gel filtration on Sephadex G50 fine (Chatelain and Dupouy, 1980b). The apparent molecular weight (MW) of the "big " form of ACTH, eluted as Blue Dextran 2000 and proteins in the void volume of the columns, is 44000 ; "little » $A C T H$, eluted in the same fractions as human synthetic $\mathrm{ACTH}_{1-39}$, has an apparent $\mathrm{MW}$ of 4500 . The third molecular form, designated as " intermediate " ACTH, elutes between the first two ; its apparent $\mathrm{MW}$ is almost 13000 . Between days 17 and 21 of gestation, a sharp rise in the 
bioreactive ACTH content of the pituitary (Dupouy, 1976) is associated with an increase in the proportion of " intermediate " and "little " forms of ACTH and a correlative decrease in the "big " form (Chatelain and Dupouy, 1980b). These three immunoreactive forms of ACTH are also found in the lobes of the fetal and neonatal pituitary glands as well as in the adult pituitary (Chatelain and Dupouy, 1985).

The "big " form of ACTH is mainly found in the pars neurointermedia of the rat fetus between days 18 and 21 of gestation, while the three immunoreactive forms are observed in newborns from weeks 1 to 4 . The "big " ACTH/total ACTH ratio, which is very high during fetal life, decreases regularly after birth (fig. 1). In 4-week old newborns, it is as low as in pregnant females (fig. 1). This ratio is always less in the pars distalis than in the pars neurointermedia. In the former it decreases during gestation and the first two weeks after birth (fig. 1). Between days 14 and 28 postpartum, this ratio is similar to that found in pregnant females. The ratio of " intermediate" + "little " ACTH/total ACTH evolves in a contrary way (fig. 1).

Similar changes occur (Silman et al., 1979) in the pituitary gland of the sheep fetus and the lamb which contains abundant material of high molecular weight (Silman, 1979 ; Silman et al., 1979 ; Roebuck et al., 1980). The ratio of pituitary concentration between the high and low molecular-weight forms of ACTH was higher in 120 to 145 -day fetuses (mean : 1.66) than in a 3-month old lamb (mean : 1.22) or pregnant ewes (mean: 0.46). Moreover, as two of the three immunoreactive forms of high molecular-weight ACTH contained amino acid sequences similar to both ACTH and $\beta$-LPH (Silman, 1979 ; Silman et al., 1979), the common precursor for ACTH and lipotrophin observed in the adults of several species could be present in the sheep fetus. These observations suggest that there is a progressive change in the proportions of the different molecular forms of pituitary ACTH in sheep as well as in rats during perinatal development.

In contrast to rats and sheep, the pituitary gland of fetal rhesus monkeys was not reported to contain a macromolecular form of ACTH (Silman et al., 1978).

The $A C \mathrm{AH}_{1-39}$ and $\beta$-LPH present in the pars distalis of the adult pituitary of several species are considered to arise from the proteolytic cleavage of a common " pro-opiomelanocorticotrophin » precursor (Liotta et al., 1978 ; Lissitsky et al., 1978 ; Jackson and Lowry, 1980). During the perinatal development of rats, the progressive disappearance of the "big" form of ACTH coupled with the appearance of the "little " form could mean that the enzyme systems involved in such cleavage at the cellular level are becoming functionally mature. The evolution of various molecular forms of ACTH are reported to be different in adult pars neurointermedia, i.e. the proteolytic cleavage of $\mathrm{ACTH}_{1-39}$ produces several peptides of lower molecular weight, such as $\alpha-\mathrm{MSH}\left(\mathrm{ACTH}_{1-13}\right.$ and CLIP $\left(\mathrm{ACTH}_{18-39}\right.$ ) (Gianoulakis et al., 1979 ; Mains and Eipper, 1979, 1980 ; Eipper and Mains, 1980); the adult pars neurointermedia contains little ACTH ${ }_{1-39}$ (Crine et al., 1979 ; Gianoulakis et al., 1979) but a lot of $\alpha-\mathrm{MSH}, \mathrm{CLIP}$ and $\beta$-endorphin (Scott et al., 1974a, b ; Kraicer, 1977 ; Lissitsky et al., 1978 ; Gianoulakis et al., 1979 ; Jackson and Lowry, 1979 ; Chretien and Seidah, 1981). This cleavage could be primed in late pregnancy or early postnatal life and might account for 

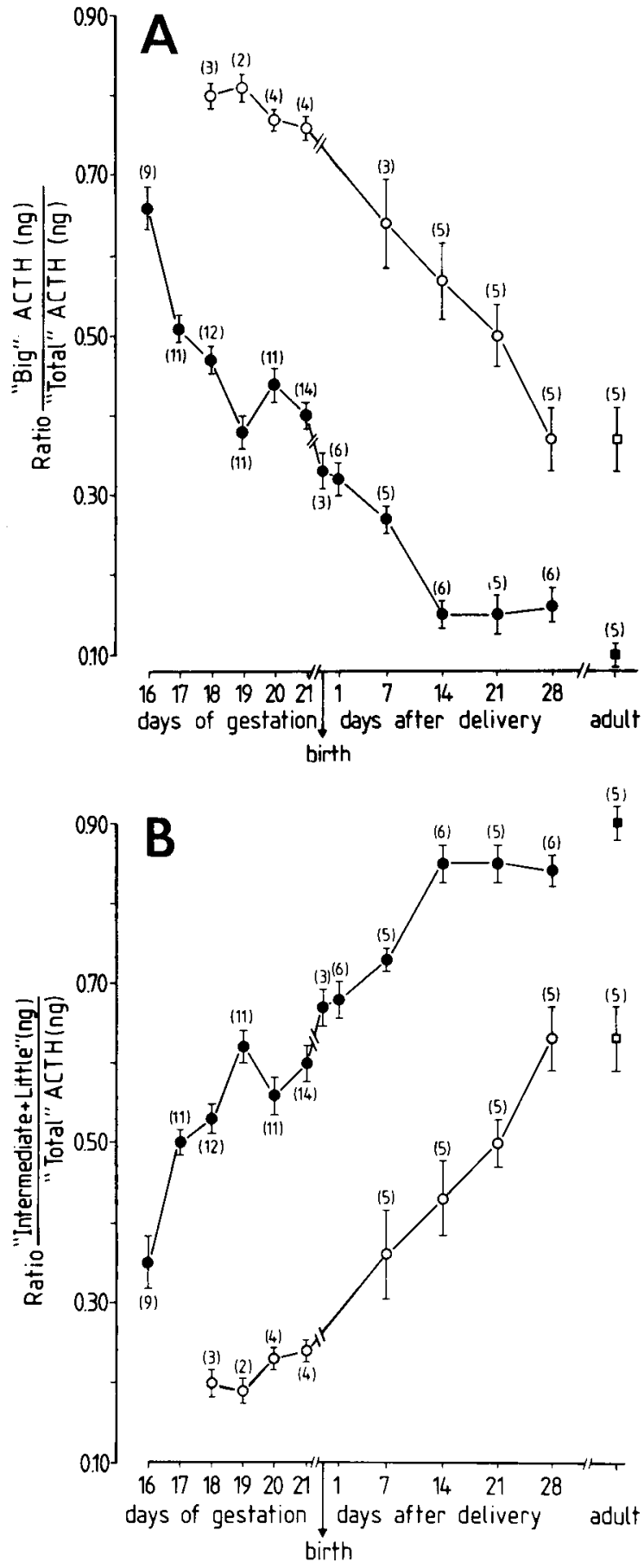

FIG. 1. - Variations in the anterior (-___ ) and neurointermediate (O__ lobes of the " big" ACTH/" total "ACTH ratio (A) and the "intermediate " and "little "ACTH/" total "ACTH ratio (B). Each point represents the mean \pm SEM ; number of chromatographs in parentheses.

Acid extracts $(0.1 \mathrm{~N} \mathrm{HCl})$ of fetal rat hypophyses were subjected to gel filtration at $4{ }^{\circ} \mathrm{C}$ on Sephadex G 50 fine columns (Pharmacia K9/60,60×0,9 cm) equilibrated and further eluted with acetic acid $0.1 \mathrm{M}$ containing $0.3 \% \mathrm{HSA}$. The flow rate was $10-15 \mathrm{ml} / \mathrm{hr}$ and $1-\mathrm{ml}$ eluate fractions were collected.

(From Chatelain and Dupouy, 1985). 
the lower $\mathrm{ACTH}_{1-39}$ (" little » form) content of the pars neurointermedia as compared to the pars distalis.

\section{B. Plasma ACTH}

1) Origin of the ACTH present in fetal circulation. - Several observations extensively discussed by Dupouy and Chatelain (1981) suggest that the fetal pituitary has both trophic and steroidogenic action on fetal adrenals. Indeed, fetal hypophysectomy performed in utero induced a sharp drop in plasma ACTH levels, adrenal atrophy and a decrease in the synthesis and release of corticosteroids: ACTH given to the fetus suppressed the effects of hypophysectomy on growth as well as on adrenal activity. The ACTH found in the fetal circulation originated mainly or exclusively from the fetus. This hypothesis is also supported by a comparison of fetal and maternal plasma ACTH levels. In man, immunoreactive ACTH concentrations are reduced in anencephalic infants compared with the levels found in full-term babies or mothers (Allen et al., 1973, 1974 ; Miyakawa et al., 1974 ; Winters et al., 1974). Similarly, plasma ACTH levels are reduced in encephalectomized rats (Dupouy and Chatelain, 1981; Chatelain and Dupouy, 1981a). At birth, ACTH concentrations are higher in the arterial than in the venous plasma of the human umbilical cord (Arai et al., 1976 ; Puolakka et al., 1982). Also, ACTH levels are higher in the arterial plasma of fetal sheep than in that of the mothers during the second half of gestation as well as during parturition (Jones et al., 1977).

Immunoreactive ACTH concentrations are reduced in infants from mothers with Nelson's syndrome (Allen et al., 1973) or from mothers infused with ACTH during labour (Miyakawa et al., 1974). Moreover, no correlation has been reported between maternal and fetal ACTH levels in man (Allen et al., 1973) or in sheep (Alexander et al., 1971). No transplacental passage of ACTH was observed when labelled hormone was given to the mother or the fetus in several species including sheep (Jones et al., 1975), rabbits (Genazzani et al., 1975) and rats (Dupouy et al., 1980). The perfusion of ACTH to rhesus monkey fetuses was unable to induce a rise in the maternal plasma ACTH level (Walsh et al., 1979).

These experimental data suggest or demonstrate that ACTH is not transported across the placenta in several species of mammals, including man, and that the ACTH present in the fetal circulation is not of maternal origin. Although some factors other than ACTH could partly control the development of fetal adrenals in mammals and man (see review in Dupouy and Chatelain, 1981), the corticostimulatory activity of the fetal pituitary is mainly due to ACTH. Therefore, quantitative and qualitative changes in plasma ACTH levels during gestation are reliable tests of the corticostimulatory action of the pituitary gland.

2) Polymorphism of circulating ACTH in the fetus and newborn. - Many studies have been done on the polymorphism of immunoreactive ACTH in adult plasma; in contrast, there are few observations concerning the plasma of the fetus and newborn.

Three molecular forms of immunoreactive ACTH are found in the fetal circulation of sheep between 115 and 125 days (Jones et al., 1978 ; Jones and 
Roebuck, 1979) and in that of rat between 17 and 21 days (Chatelain and Cheong, $1985 \mathrm{a}$, b) of pregnancy. In the latter species, these forms are similar to those observed in the fetal pituitary (Chatelain and Dupouy, 1985b). High molecular forms of ACTH are also present in the plasma of fetal monkeys and guinea-pigs (Jones and Roebuck, 1979).

The proportions of the different immunoreactive forms of ACTH vary during gestation in rats. The "big " $\mathrm{ACTH} /$ total $\mathrm{ACTH}$ ratio gradually decreases, whereas the "little " ACTH/total ACTH ratio gradually increases (fig. 2), as also shown in the anterior lobe of the pituitary gland (Chatelain and Dupouy, 1985b). A similar evolution of these forms is reported for the plasma of fetal monkeys, sheep and guinea-pigs (Jones, 1976b ; Jones and Roebuck, 1979). In the plasma of the rat fetus, the " intermediate » $\mathrm{ACTH} /$ total $\mathrm{ACTH}$ ratio is higer on days 17 and 19 of gestation than at term on day 21. The rise in the low molecular form of ACTH in the fetal plasma has been correlated with the progressive disappearance of the higher forms (Chatelain and Cheong, 1985a, b). The plasma ACTH levels of newborn rats are so low (Dupouy and Chatelain, 1981 ; Chatelain and Cheong, 1985b) that the different molecular forms of ACTH cannot be identified by gel filtration. However, the "little" form is quite abundant in the plasma of 1 or 2month old male and female rats subjected to ether inhalation (unpublished data).

\section{Released and circulating molecular forms of ACTH}

A. Release of ACTH by fetal rat pituitary glands in vitro. - Is the evolution of plasma ACTH heterogeneity during gestation the result of both a selective
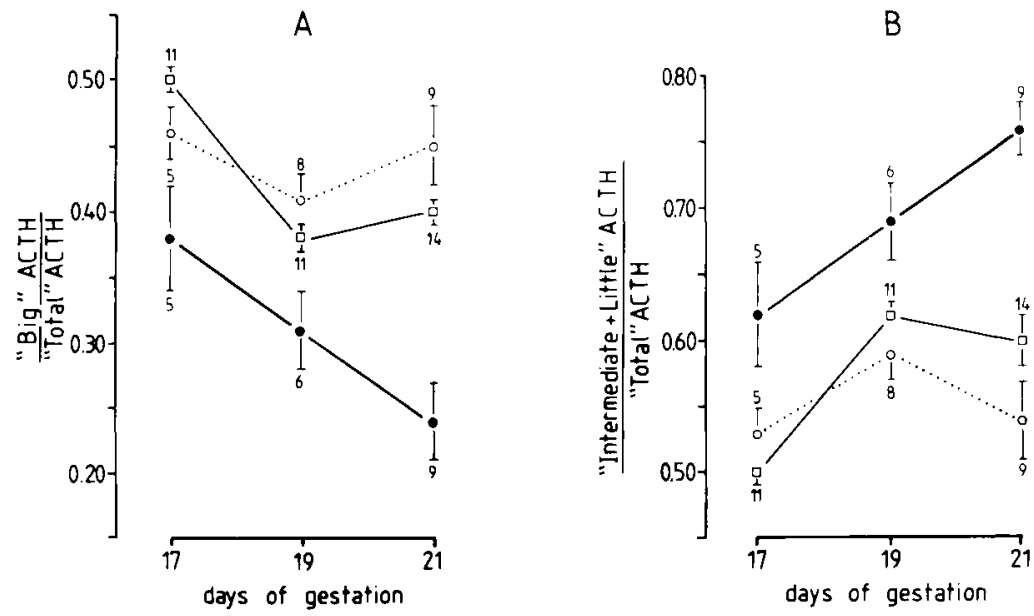

FIG. 2. - Variations of the "big" ACTH/" total "ACTH ratio (A) and the "intermediate" + "little " ACTH/" total" ACTH ratio (B) in the plasma gland anterior lobe (....) and in the anterior lobe (1 (-) in the perfusate of pituitary 17, 19 and 21 of gestation. Each point represents the mean \pm SEM; the number of chromato grams is indicated. 
secretion of the different molecular forms of pituitary ACTH and/or a further protease-induced conversion in the fetal circulation? As in vivo study of the ACTH released by both lobes of the fetal pituirary is impossible, Chatelain and Cheong (1985a, b) investigated in vitro ACTH release by the pars distalis of the fetal gland collected at different stages of gestation (days 17, 19 and 21) and stimulated with a crude extract of adult hypothalamus. The effluent perfusate was collected in 1-ml fractions which were subjected to gel filtration on Sephadex G50 fine, according to the procedure used previously for plasma studies.

Three immunoreactive forms of $\mathrm{ACTH}$, isolated by chromatography of anterior lobe perfusate, were similar to those previously observed in the fetal plasma and pituitary gland (Chatelain and Cheong, 1985a). Moreover, on days 17, 19 and 21 of gestation, the fetal pituitary in vitro released the same proportions of all the molecular forms of ACTH it contained (fig. 2). If the same type of release occurs in vivo, this does not explain why the proportions between the three molecular forms of ACTH are so different in the fetal circulation and mainly on day 21 of gestation. Indeed, at term the ratio of "intermediate " + "little " ACTH/total ACTH is significantly greater in the fetal plasma than in the pars distalis and the lobe perfusate (fig. 2). In vivo, plasma ACTH could arise from the pars distalis as well as from the pars neurointermedia ; however, as the "big " form of $\mathrm{ACTH}$ is found in the latter and represents less than $10 \%$ of the pituitary ACTH content, the pars distalis of the pituitary gland is the main source of circulating ACTH.

The different forms of ACTH identified in fetal sheep plasma are also found in isolated anterior pituitary cells as well as in their incubation medium (Jones, 1976a). The predominant forms of immunoreactive ACTH released in both basal and [Arg-]-vasopressin (AVP)-stimulated cultures are the same as the major forms contained in the pituitary cells of mice (Paquette et al., 1979) or rats (Eipper and Mains, 1978 ; Zimmerman and Kraicer, 1978; Itoh et al., 1981). These data suggest that the evolution of ACTH polymorphism in the fetal plasma might not reflect a selective release of the molecular-weight forms of ACTH by the pituitary but some proteolytic modification after secretion into the fetal circulation.

B. Conversion of released forms of ACTH in the circulation . - Several findings strengthen the hypothesis that high molecular-weight forms of ACTH are converted by the action of plasmin or trypsin into "little " forms. Indeed, fetal sheep blood or plasma when incubated at $37^{\circ} \mathrm{C}$ induces a sharp rise in bioactive ACTH concentration $(600 \%)$ associated with the conversion of the high molecular-weight form of ACTH into « little " ACTH of higher biological activity (Jones, 1976b). This process is slower with incubation at $4{ }^{\circ} \mathrm{C}$ and inhibited by lima bean trypsin inhibitor or by pre-heating the plasma at $80^{\circ} \mathrm{C}$ for $60 \mathrm{~min}$.

Controlled tryptic digestion in vitro of fetal rat " big " ACTH which has low biological activity (Chatelain and Dupouy, 1985) leads to the appearance of " intermediate " and "little " forms of ACTH (Chatelain and Cheong, 1985a, b) of high steroidogenic potency (Chatelain and Dupouy, 1985). However, when " intermediate » $\mathrm{ACTH}$ is submitted to tryptic digestion in the same conditions, 
there is continuous loss of immunoreactivity but no change of hormonal form (fig. 3).

Yalow and Berson (1973) studying the pituitary gland and plasma and Gewirtz et al., (1974) ectopic tumors showed the conversion of human ACTH into its "little » form. Trypsin-induced conversion of "big " ACTH into the " intermediate " form was observed in mice (Coslovsky et al., 1975). In contrast, " intermediate " ACTH was not a precursor of the "small " form in rabbits and cattle (Coslovsky and Yalow, 1974) or mice (Coslovsky et al., 1975).

These data suggest that the "big " form of ACTH in both adult and fetal plasma is converted into " intermediate " and "little " forms by the action of proteases. Such conversion might be higher in term fetuses than in younger ones.

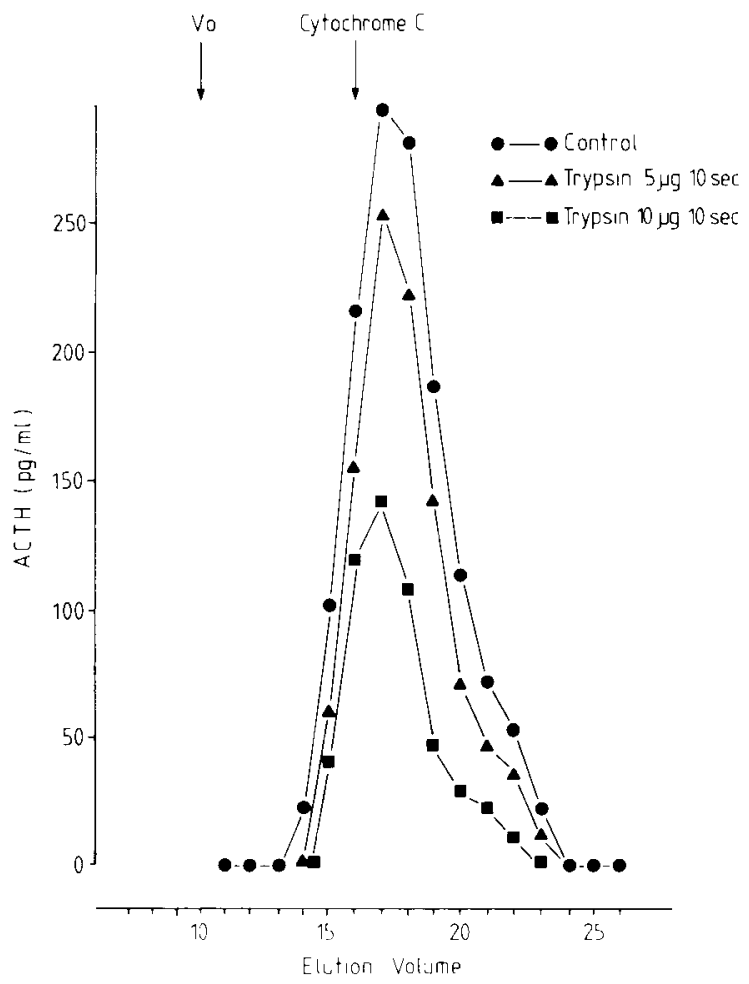

FIG. 3. - Sephadex G50 fine filtration of the "intermediate " immunoreactive form of ACTH isolated from an acid extract $(0.1 \mathrm{~N} \mathrm{HCl})$ of twenty anterior lobes of 21 day-old fetuses, before $(\bullet-\longrightarrow)$ and 10 sec after controlled digestion with $5 \mu \mathrm{g}(\mathrm{A}$ $\Delta$ ) or $10 \mu \mathrm{g}$

) of trypsin.

Chromatography was performed at $4{ }^{\circ} \mathrm{C}$ on Sephadex G50 fine columns (Pharmacia K9/60, $60 \times 0.9 \mathrm{~cm})$ previously equilibrated and eluted with $1 \%$ formic acid containing $100 \mathrm{mg}$ of polypep $/ 100 \mathrm{ml}$. The flow rate was $10-14 \mathrm{ml} / \mathrm{hr}$ and $1 \mathrm{ml}$ eluate fractions were collected in polyethylene tubes. Before ACTH radioimmunoassay the fractions were evaporated and reconstituted with $0.02 \mathrm{M}$ veronal buffer; $\mathrm{pH}$ was adjusted to 8.2 with $5 \mathrm{~N} \mathrm{NaOH}$.

(Original data) 


\section{Biological activity of different molecular forms of ACTH}

A. In vitro and in vivo corticosteroidogenic activity. - Low biological activity is reported to be associated with the "big " ACTH form isolated from the pituitary of adult rats (Zimmerman and Kraicer, 1978) and mice (Mains and Eipper, 1975 ) as well as from mouse pituitary tumors (Mains and Eipper, 1975) or human ectopic carcinoma (Gewirtz et al., 1974). Gasson (1979) studied the biological activity of three high molecular-weight forms of ACTH in isolated rat adrenal cortex cells; the three forms (pro-ACTH/endorphin or "big " ACTH, biosynthetic " intermediate " or $23000 \mathrm{MW} \mathrm{ACTH}$, and glycosylated $\mathrm{ACTH}_{1-39}$ or $13000 \mathrm{MW}$ ACTH) could stimulate corticosterone release; however, proACTH/endorphin and glycosylated $\mathrm{ACTH}_{1-39}$ were 100 and 300 -fold less potent, respectively, than $\mathrm{ACTH}_{1-39}$. These observations disagree with those of Estivariz and Iturriza (1975) who detected high biological activity associated with "big " ACTH in the anterior and neurointermediate lobes of adult rats.

Fetal material has hardly been investigated. Roebuck et al., (1980) studying fetal adrenal cells of 130 to 135-day old lambs showed that three high molecularweight forms of ACTH (50 000,30000 and 20000$)$ were each biologically active but blocked ACTH corticosteroidogenic activity.

Macromolecular peptides in the fetal circulation might explain why fetal sheep adrenals are apparently less responsive to exogenous ACTH in vivo than in vitro, and they could explain the paradoxical effect of short-term dexamethasone infusion into fetal sheep which increases response to $\mathrm{ACTH}_{1-24}$ (Liggins et al., 1977). Dexamethasone could reduce the secretion of large inhibitory peptides as well as that of $\mathrm{ACTH}_{1-39}$. Similarly, dexamethasone increases adrenal response to exogenous ACTH in fetal rhesus monkeys (Novy and Walsh, 1981) while, without dexamethasone, this response is irregularly observed in vivo (Kittinger and Beamer, 1971 ; Jaffe et al., 1977). However, isolated adrenal cells in vitro are responsive to physiological concentrations of ACTH (Roebuck et al., 1984). The inhibition of $\mathrm{ACTH}_{1-39}$ bioactivity by macromolecular forms could be related to the presence in their molecule of the 15-18 ACTH sequence which, by occupying corticotropin membrane receptors might prevent $\mathrm{ACTH}_{1-39}$ from exercising its corticosteroidogenic activity (Hofmann, 1974 in Roebuck et al., 1980). According to Gasson (1979), the low steroidogenic potency of biosynthetic " intermediate » ACTH and pro-ACTH/endorphin would be due to the addition of the 16000 fragment extension on the amino terminal side of the $A C T H_{1-39}$ sequence. However, according to Gewirtz et al., (1974), when present in 5-fold excess (on the basis of immunological equivalence) "big " ACTH extracted from human non-pituitary tumors had no inhibitory effect on the biological potency of standard ACTH.

The perfusion of 21-day old rat fetus adrenals with the same immunological quantities (2 ng) of " big ", " intermediate " or " little » ACTH isolated from fetal pituitary showed that "big », ACTH has weak corticosteroidogenic activity, whereas " intermediate " and "little " ACTH highly stimulate corticosterone release (Chatelain and Dupouy, 1985). Moreover, with adrenals from 17, 19 and

Reproduction, Nutrition, Développement $n^{\circ} 5-1985 . \quad 8$ 
21-day old fetuses, the production of corticosterone induced by "little " and " intermediate " ACTH is log-dose-dependent (fig. 4).

An immunologically equivalent amount $(2 \mathrm{ng})$ of " intermediate » and "little " $A C T H$, which does not induce maximal response shows similar corticosteroidogenic activity on adrenals of 17 and 19-day old fetuses (fig. 5), whereas " little » ACTH has greater biological potency than the " intermediate " form on fetal adrenals at term (fig. 5).

To interpret differences in potency obtained with these ACTH forms on fetal adrenals, it is necessary to understand their fate in the assay system and to determine changes in the number, specificity and affinity of the related adrenal receptors during gestation.

B. The physiological meaning of ACTH polymorphism. - The physiological meaning of $\mathrm{ACTH}$ heterogeneity and its evolution during perinatal development is not well known.

According to the hypothesis of Coslovsky and Yalow (1974), the hormonal form of ACTH would be an important factor regulating the cortisol/corticosterone ratio in mammalian adrenal corticoid secretion. "Little " ACTH is reported to predominate in mammals primarily producing cortisol (humans, monkeys, sheep, dogs, cats, guinea-pigs), whereas " intermediate » ACTH is more important in mammals in which corticosterone predominates (rabbits, rats, mice). As the main hormones released by fetal and newborn adrenals are reported to change during

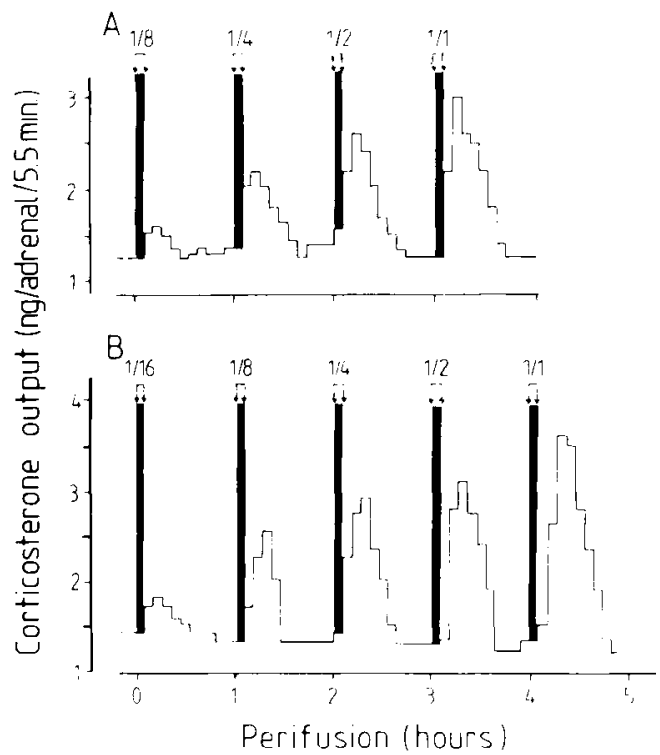

FIG. 4. - Biological activity of " intermediate " (A) and "little " (B) ACTH forms on perifused adrenals of 19-day old rat fetuses. Corticosterone content of $1 \mathrm{ml}$ eluate fractions collected during $5.5 \mathrm{~min}$ was determined by radiocompetition. The production of corticosterone induced by the " intermediate " and "little " ACTH forms was log-dose-dependent $(A: y=7.36 \log x-7.30$; $r=0.974 ; B: y=6.33 \log x-3.85 ; r=0.995)$. 


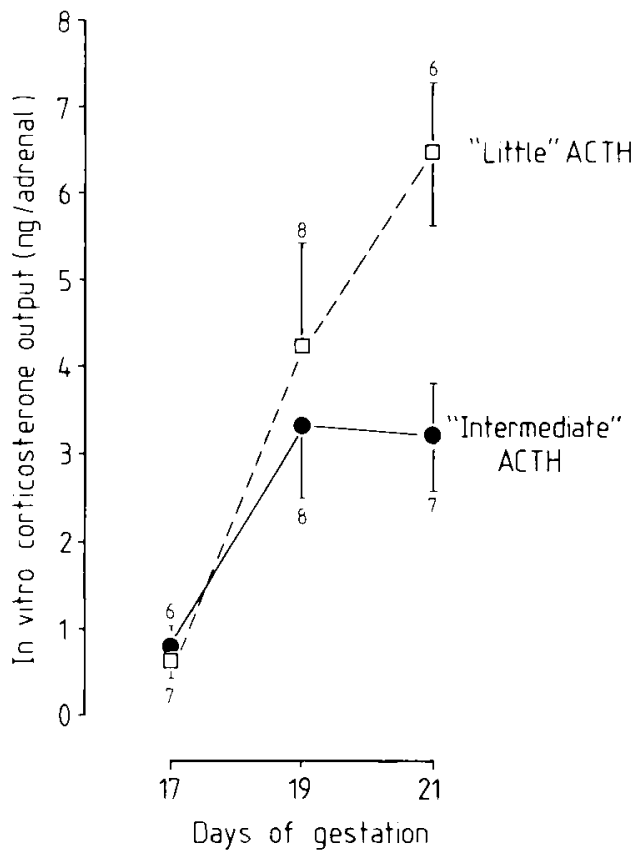

FIG. 5. - Biological activity of equivalent amounts $(2 \mathrm{ng})$ of the "intermediate " and "little "ACTH forms on perifused adrenals of 17, 19 and 21-day old rat fetuses. This dose did not induce maximal response.

The corticosterone content of $1-\mathrm{ml}$ eluate fractions was determined by radiocompetition.

(Original data)

the development of species such as rats, sheep and rabbits (see review in Chatelain and Dupouy, 1980b), it is possible that these drastic changes in adrenal activity are related to the evolution of the different molecular forms of ACTH during the perinatal period. However, Coslovsky and Yalow (1974) as well as Yalow and Berson (1971) performed gel filtration with a non-dissociative basic buffer containing plasma protein so that some ACTH molecules might have bound to albumin and other proteins, modifying the elution profiles (Ratter et al., 1980). For example, adult rat pituitary extracts chromatographied under acid conditions contain the "little " form of ACTH (Lang et al., 1973 ; Estivariz and Iturriza, 1975 ; Itoh et al., 1981) associated with either the " intermediate " form (Lang et al., 1973) or the " big " one (Estivariz and Iturriza, 1975) or both these forms (Itoh et al., 1981). In contrast, under basal conditions, Coslovsky and Yalow (1974) indentified only the "intermediate " form of ACTH. Similarly, besides a minor " big » molecular form, pituitary extracts of adult mice were reported to contain two equivalent major forms related to the "little " and " intermediate » forms when chromatographied under acid conditions (Mains and Eipper, 1975) or subjected to electrophoresis on SDS-polyacrylamide gel (Paquette et al., 1979). In contrast, Coslovsky and Yalow (1974) identified only " intermediate " ACTH when gel filtration was performed with basic buffer. 
Such discrepancies make it difficult to assert some link between ACTH polymorphism in the fetus and the newborn and the functional differentiation of the adrenals during the perinatal period.

C. Quantitative and qualitative modulation of the corticostimulatory activity of the fetal and neonatal pituitary. - Adrenal growth and adrenal and plasma corticosterone concentrations, which are used extensively as indirect but reliable tests of corticostimulatory activity in rat fetuses, suggest that this pituitary function increases between days 17 and 19 of gestation and then decreases until term (see review in Dupouy and Chatelain, 1981). During the last 3 days of gestation, pituitary corticotropic activity depends on both hypothalamic control and negative steroid feedback (see review in Dupouy and Chatelain, 1981). Immunoreactive ACTH levels reach a peak in the plasma of 18 to 19-day old fetuses (Chatelain et al., 1980 ; Boudouresque et al., 1984 ; Chatelain and Cheong, 1985b) in correlation with the activity of the fetal adrenals (fig. 6). The determination of plasma ACTH contents by either immunological or biological assay cannot account for the heterogeneity of the circulating forms of ACTH which differ in their biological and immunological activity as well as in their apparent molecular weight. The corticostimulatory activity of the fetal pituitary rises between days 17 and 19 of gestation due to the quantitative increase in plasma ACTH and to the qualitative change in circulating ACTH. Indeed, the proportion of bioactive forms (" little " and " intermediate ") increases over the "big " form which shows low biological activity.

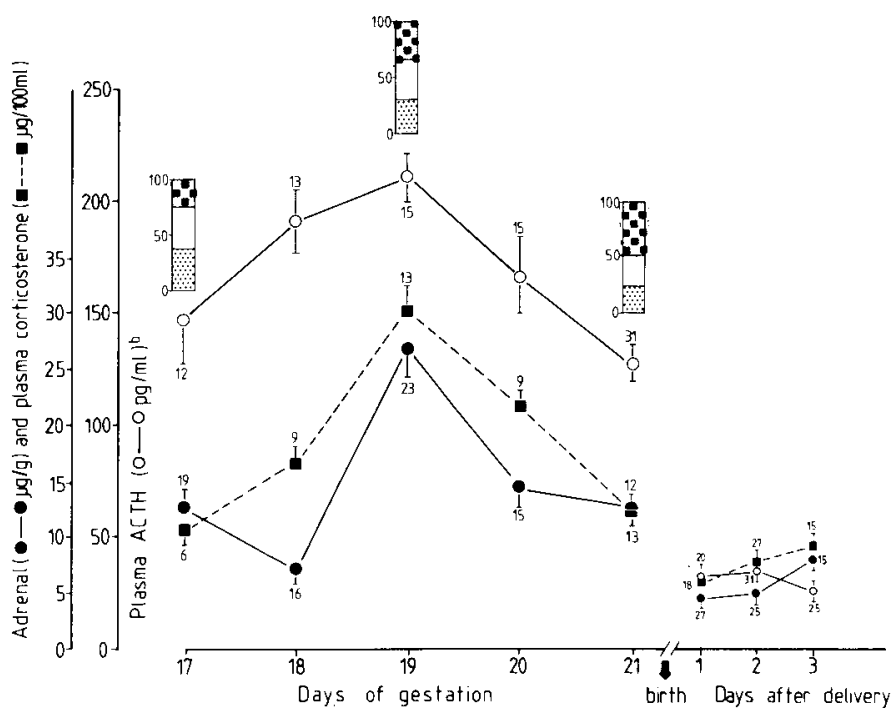

FIG. 6. - Immunoreactive plasma ACTH levels in rat fetuses (a) and newborns (b) in relation to adrenal and plasma corticosterone concentrations in fetuses (c) and newborns (b).

Vertical columns: percentage of the different molecular forms of ACTH; 6 big ",

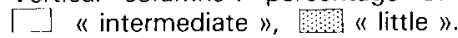

(Data adapted from (a) Chatelain and Cheong, 1985 ; (b) Dupouy and Chatelain (original data), (c) Dupouy, Coffigny and Magre, 1975.) 
Beyond day 19, the decrease in pituitary gland corticostimulatory activity is mainly due to a drop in ACTH secretion.

In early postnatal life, the plasma free corticosterone concentration rises significantly (Koch et al., 1967) owing to the precipitous drop in corticosteroidbinding globulin (CBG) activity (Koch et al., 1967; Nuñez et al., 1971 ; Martin et al., 1977 ; Van Baelen et al., 1977 ; Raymoure and Kuhn, 1983 ; Dupouy and Chatelain, 1985); this results in a sharp decrease in pituitary ACTH secretion under the negative feedback effect of plasma corticosterone. The fall in plasma ACTH levels could be related to a reduction in both the adrenal and plasma corticosterone concentrations in newborn rats.

No study has been done on ACTH polymorphism in the plasma of newborns. However, it is possible that the evolution observed during fetal life simply continues after birth.

\section{Conclusion.}

A drastic change in ACTH polymorphism occurs in both the pituitary and the plasma of mammals during perinatal development. This change is probably linked to functional maturation of the enzyme systems involved in the conversion of the high molecular-weight (" big ») form of ACTH with low biological activity into lower molecular-weight (" intermediate" and "little ") forms with higher corticosteroidogenic activity. Nevertheless, the physiological meaning of ACTH heterogeneity during the perinatal period is not well understood. The action mechanism of these different forms of ACTH on fetal and neonatal adrenals has yet to be defined.

Acknowledgements. - The authors wish to express their gratitude to J. P. Pozzo Di Borgo, N. Delatte and J. B. Zazac for technical assistance and to N. Chatelain for reading the English manuscript.

Résumé. Hétérogénéité de l'ACTH hypophysaire et plasmatique dans la période périnatale.

1) La filtration sur gel de Sephadex G50 fine d'extraits acides de lobes antérieurs (LA) et neurointermédiaires (LNI) d'hypophyses de fœtus et de nouveau-nés de rat met en évidence trois formes immunoréactives de l'ACTH caractérisées par leur poids moléculaire apparent (P. M.) et leur activité biologique.

La forme " big ", dont le P. M. est voisin de 44000 , stimule peu la production de corticostérone par des surrénales fœtales périfusées.

Les formes " intermédiaire " (P. M. $\simeq 13000)$ et "little " (P. M. $\simeq 4500)$ ont par contre in vitro, une forte activité biologique log-dose dépendante.

La proportion entre ces formes varie au cours de la vie intrautérine et postnatale.

Dans les LNI de fœtus, prédomine la forme "big "; après la naissance, le rapport " big " ACTH/ACTH totale décline régulièrement pour atteindre chez le nouveau-né de 4 semaines, une valeur comparable à celle de $\$$ adultes gestantes. 
Dans les LA coexistent les trois formes de l'ACTH mais, au cours de la période périnatale, la proportion de la forme "big " diminue tandis que celle des formes "little " et " intermédiaire " augmente.

2) In vitro, des LA d'hypophyses de fotus de 17, 19 et 21 jours stimulées par un extrait d'hypothalamus d'adulte sécrètent les trois formes immunoréactives de l'ACTH dans les mêmes proportions que celles déterminées dans les adénohypophyses.

3) Dans le plasma de fœetus âgés de 17, 19 et 21 jours, I'ACTH se présente sous trois formes immunoréactives analogues à celles observées dans l'hypophyse. Au cours de la gestation, le rapport de concentration ACTH « big »/ACTH totale diminue alors que le rapport ACTH " little "/ACTH totale augmente. A terme, la proportion de "little " dans le plasma est plus grande que dans l'hypophyse.

4) La digestion trypsique ménagée des formes "big " et "intermédiaire " montre que la forme " big " doit être un précurseur des formes "little " et " intermédiaire " mais que cette dernière n'est pas un précurseur de la "little ".

In vivo, une transformation de ces formes moléculaires de l'ACTH est suggérée dans la circulation du foetus à terme.

5) Une bonne corrélation paraît exister entre l'ACTHémie du fœtus qui présente un maximum à 19 jours et l'activité de la corticosurrénale fœetale. Dans les jours qui suivent la naissance, l'ACTHémie s'effondre et la surrénale du nouveau-né est faiblement active.

Au cours de la vie fœetale, l'activité corticostimulante de l'hypophyse paraît être modulée quantitativement par le taux de sécrétion de l'ACTH et qualitativement par l'activité biologique des différentes formes moléculaires de I'ACTH sécrétée.

\section{References}

ALEXANDER D. P., BRITTON H. G., FORSLING M. L., NIXON D. A., RATCLIFFE J. G., 1971. The concentrations of adrenocorticotrophin, vasopressin and oxytocin in the foetal and maternal plasma of the sheep in the latter half of gestation. J. Endocrinol., 49, 179-180.

ALLEN J. P., COOK D. M., KENDALL J. W., McGILVRA R., 1973. Maternal fetal ACTH relationship in man. J. clin. Endocrinol. Metab., 37, 230-234.

ALLEN J. P., GREER M. A., McGILVRA R., CASTRO A., FISHER D. A., 1974. Endocrine function in an anencephalic infant. J. clin. Endocrinol., Metab., 38, 94-98.

ARAI K., YANAIHARA T., OKINAGA S., 1976. Adrenocorticotropic hormone in human fetal blood at delivery. Am. J. Obstet. Gynecol., 125, 1136-1140.

BOUdOURESQUE F., GUILLAUME V., STRBAK V., REY M., CASTANAS E., OLIVER C., DUTOUR A., CONTE-DEVOLX B., 1984. Influence de la corticoliberine endogène sur la sécrétion d'ACTH et de la corticostérone chez le rat pendant la vie fotale. Ann. Endocrinol., 45, $16 \mathrm{~N}$.

CHATELAIN A., CHEONG H. S., 1985a. Etude in vivo et in vitro du polymorphisme de I'ACTH sécrétée par l'hypophyse fœetale du rat, au cours de la gestation. Assoc. Physiol, Réunion de Valence, Espagne, J. Physiol, (Paris) 80, 9A.

CHATELAIN A., CHEONG H. S., 1985b. Immunoreactive forms of ACTH released by the adenohypophysis during the perinatal period. (Soumis pour publication).

CHATELAIN A., DUPOUY J. P., 1980a. L'ACTH des lobes antérieur et neurointermédiaire de I'hypophyse chez le fœtus de rat au cours de la gestation. J. Physiol. (Paris), 76, 29A-30A.

CHATELAIN A., DUPOUY J. P., 1980b. Activité biologique et immunoréactivité des différentes formes moléculaires de l'ACTH hypophysaire chez le foetus de rat. J. Physiol. (Paris), 76. 257-263.

CHATELAIN A., DUPOUY J. P., 1981a. Activity of the pituitary-adrenal system in rat fetuses subjected to encephalectomy in early or late stages of pregnancy. Neuroendocrinology, 33, 148152.

CHATELAIN A., DUPOUY J. P., 1981b. Adrenocorticotrophic hormone in the anterior and neurointermediate lobes of the fetal rat pituitary gland. J. Endocrinol., 89, 181-186.

CHATELAIN A., DUPOUY J. P., 1985. Adrenocorticotrophic hormone in the anterior and neurointermediate lobes of the rat during the perinatal period: polymorphism, biological and immunological activities of ACTH. Biol. Neonate 47, 235-248. 
CHATELAIN A., DUPOUY J. P., ALLAUME P., 1980. Fetal-maternal adrenocorticotropin and corticosterone relationships in the rat: effects of maternal adrenalectomy. Endocrinology, 106, 1297-1303.

CHATELAIN A., DUPOUY J. P., DUBOIS M. P., 1979. Ontogenesis of cells producing polypeptide hormones $(\mathrm{ACTH}, \mathrm{MSH}, \mathrm{LPH}, \mathrm{GH}$, Prolactin) in the fetal hypophysis of the rat : Influence of hypothalamus. Cell. Tissue Res., 196, 409-427.

CHRETIEN M., SEIDAH N. G., 1981. Chemistry and biosynthesis of pro-opiomelanocortin ACTH, MSH's, endorphins and their related peptides. Molec. cell. Biochem., 34, 101-127.

COSLOVSKY R., YALOW R. S., 1974. Influence of hormonal forms of ACTH on the pattern of corticosteroid secretion. Biochem. biophys. Res. Commun., 60, 1351-1356.

COSLOVSKY R., SCHNEIDER B., YALOW R. S., 1975. Characterization of mouse ACTH in plasma and in extracts of pituitary and of adrenotropic pituitary tumor. Endocrinology, 97, 1308-1315.

CRINE P., GOSSARD F., SEIDAH M. G., BLANCHETTE L., LIS M., CHRETIEN M., 1979. Concomitant synthesis of $\beta$-endorphin and $\alpha$-melanotropin from two forms of pro-opiomelanocortin in the rat pars intermedia. Proc. nat. Acad. Sci. (USA), 76, 5085-5089.

DUPOUY J. P., 1976. Evolution de la teneur de l'hypophyse fœetale en ACTH. Etude chez le rat, en fin de gestation. C. R. Acad. Sci. Paris, 282, 211-214.

DUPOUY J. P., CHATELAIN A., 1981. La fonction corticotrope dans la période périnatale: ontogenèse et régulation. J. Physiol. (Paris), 77, 955-968.

DUPOUY J. P., CHATELAIN A., 1985. Activité hypophyso-surrénalienne chez le fœtus de Rat normal, le nouveau-né et le postmature. Assoc. Physiol., Réunion de Valence, Espagne 910 nov. 1984. J. Physiol. (Paris) 80, 10A.

DUPOUY J. P., CHATELAIN A., ALLAUME P., 1980. Absence of transplacental passage of ACTH in the rat : direct experimental proof. Biol. Neonate, 37, 96-102.

DUPOUY J. P., COFFIGNY H., MAGRE S., 1975. Maternal and foetal corticosterone levels during late pregnancy in rats. J. Endocrinol., 65, 347-352.

EIPPER B. A., MAINS R. E., 1975. High molecular weight forms of adrenocorticotropic hormone in the mouse pituitary and in a mouse pituitary tumor cell line. Biochemistry, 14, 3836-3844.

EIPPER B. A., MAINS R. E., 1978. Existence of a common precursor to ACTH and endorphin in the anterior and intermediate lobes of the rat pituitary. J. Supramol. Struct., 8, 247-262.

EIPPER B. A., MAINS R. E., 1980. Structure and biosynthesis of pro-ACTH/endorphin and related peptides. Endocr. Rev., 1, 1-27.

EIPPER B. A., MAINS R. E., GUENZI D., 1976. High molecular weight forms of adrenocorticotropic hormone are glycoproteins. J. biol. Chem., 251, 4121-4126.

ESTIVARIZ F.E., ITURRIZA F. C., 1975. "Big " and "small " ACTH in the partes distalis and intermedia of rats and toads. Gen. comp. Endocr., 27, 408-411.

GASSON J. C., 1979. Steroidogenic activity of high molecular weight forms of corticotropin. Biochemistry, 18, 4215-4224.

GENAZZANI A. R., FRAIOLI F., FIORETTI P., FELBER J. P., 1975. Placental impermeability to maternal ACTH in the rabbit. Experientia, 31, 245-247.

GEWIRTZ G., SCHNEIDER B., KRIEGER D. T., YALOW R. S., 1974. Big ACTH : conversion to biologically active ACTH by trypsin. J. clin. Endocrinol. Metab., 38, 227-230.

GIANOULAKIS C., SEIDAH N. G., ROUTHIER R., CHRETIEN M., 1979. Biosynthesis and characterization of adrenocorticotropic hormone, $\alpha$-melanocyte-stimulating hormone, and an $\mathrm{NH}_{2}$ terminal fragment of the adrenocorticotropic hormone/ $\beta$ lipotropin precursor from rat pars intermedia J. biol. Chem., 254, 11903-11906.

HOFMANN K. 1974. Relations between chemical structure and function of adrenocorticotropin and melanocyte-stimulating hormones. In : GREEP R.O. et al. Handbook of Physiology, sect. 7, part 2, vol. 4, 29-58. Am. physiol. Soc., Washington, DC.

ITOH Y., IIDA S., MORIWAKI K., TARUI S., KAWAKAMI F., 1981. Changes in distribution of molecular weight forms of biologically active and immunoreactive adrenocorticotropic hormone after adrenalectomy in rat anterior pituitary. Endocrinol. japon., 28, 685-695.

JACKSON S., LOWRY P. J., 1979. Characterization of corticotropin/endorphin related peptides in the pituitary gland and plasma of the rat. J. Endocrinol., 80, $5 \mathrm{p}$.

JACKSON S., LOWRY P. J., 1980. Distribution of adrenocorticotrophic and lipotrophic peptides in the rat. J. Endocrinol., 86, 205-219. 
JAFFE R. B., SERON-FERRE M., HUHTANIEMI 1., KARENBROT C., 1977. Regulation of the primate fetal adrenal gland and testis. J. Steroid Biochem., 8, 479-490.

JONES C. T., 1976a. Heterogeneity of adrenocorticotrophin and its secretion by pituitary cells. J. Endocrinol., 68, 23 p-24 p.

JONES C.T., 1976b. Adrenocorticotrophin transformation and degradation in blood. J. Endocrinol., 71, $62 \mathrm{p}-63 \mathrm{p}$.

JONES C. T., BODY K., ROBINSON J. S., 1977. Changes in the concentration of adrenocorticotropin and corticosteroid in the plasma of foetal sheep in the latter half of pregnancy and during labour. J. Endocrinol., 72, 293-300.

JONES C. T., ROEBUCK M. M., 1979. ACTH peptides and the development of the fetal adrenal. 4th int. Symp. J. Steroid Biochem., Paris 28-30 May 1979, $35 \mathrm{p}$.

JONES C. T., JOHNSON P., KENDALL J. Z., RITCHIE J. W. K., THORBURN G. D., 1978. Induction of premature parturition in sheep : adrenocorticotrophin and corticosteroid changes during infusion of synacthen into the foetus. Acta endocrinol., 87, 192-202.

JONES C. T., LUTHER E., RITCHIE J. W. K., WORTHINGTON D., 1975. The clearance of ACTH from the plasma of adult and fetal sheep. Endocrinology, 96, 231-234.

KITTINGER G. W., BEAMER N. B., 1971. Ontogeny of adrenal function in foetal and neonatal rhesus monkeys : in vitro corticosteroidogenesis. Endocrinology, 89, 86-95.

KOCH B., MIALHE-VOLOSS C., STUTINSKY F., 1967. Fractions liées et libres de la corticostérone plasmatique au cours du développement postnatal chez le Rat. C.R. Acad. Sci. Paris, 264, 2497-2500.

KRAICER J., 1977. Control of ACTH and MSH release from the pars intermedia : in vitro studies, 200-207. In TILDERS F.J.H., SWAAB D.F., VAN WIMERSMAN GREIDANUS T.B., Frontiers in hormone research. Karger, Basel.

LANG R. E., FEHM H. L., VOIGT K. H., PFEIFFER E. F., 1973. Two ACTH species in rat pituitary gland. Febs Letters, 37, 197-199.

LIGGINS G. C., FAIRCLOUGH R. J., GRIEVES S. A., FORSTER C. S., KNOX B. S., 1977. In O'CONNOR M., KNIGHT J. The fetus and birth. Ciba Found. Symp. $n^{\circ} 47$. Assoc. sci. Publ. Amsterdam, 5-25.

LIOTTA A. S., SUDA T., KRIEGER D. T., 1978. $\beta$-lipotropin is the major opioid-like peptide of human pituitary and rat pars distalis : lack of significant $\beta$-endorphin. Proc. nat. Acad. Sci. (USA), 75, 2950-2954.

LISSITSKY J. C., MORIN O., DUPONT A., LABRIE F., SEIDAH N. G., CHRETIEN M., LIS M., COY D. H., 1978. Content of beta-LPH and its fragments (including endorphins) in anterior and intermediate lobes of the bovine pituitary gland. Life Sci., 22, 1715-1722.

LOWRY P. J., HOPE J., SILMAN R. E., 1976. The evolution of corticotropin, melanotropin and lipotropin. Proc. 5th int. Congr. Endocrinol., vol. 1, 71-76. Ed. V.H.T. JAMES. Excerpta med. Amsterdam.

MAINS R. E., EIPPER B. A., 1975. Molecular weights of adrenocorticotropic hormone in extracts of anterior and intermediate posterior lobes of mouse pituitary. Proc. nat/. Acad. Sci. (USA), 72, 3565-3569.

MAINS R. E., EIPPER B. A., 1979. Synthesis and secretion of corticotropins, melanotropins and endorphins by rat intermediate pituitary cells. J. biol. Chem., 245, 7885-7894.

MAINS R. E., EIPPER B. A., 1980. Biosynthetic studies on ACTH, $\beta$-endorphin, and $\alpha$-melanotropin in the rat. Ann. N.Y. Acad. Sci, 343, 94-110.

MARTIN C. E., CAKE M. H., HARTMANN P. E., COOK I. F., 1977. Relationship between foetal corticosteroids, maternal progesterone and parturition in the rat. Acta endocrinol., 84, 167176.

MIYAKAWA I., IKEDA I., MAEYAMA M., 1974. Transport of ACTH across human placenta. J. clin. Endocr. Metab., 39, 440-442.

NAKANISHI S., INOUE A., KITA T., NAKAMURA M., CHANG A. C. Y., COHEN S. N., NUMA S., 1979. Nucleotide sequence of cloned DNA for bovine corticotropin- $\beta$-lipotropin precursor. Nature, 278, 423-427.

NOVY M. J., WALSH S. W., 1981. Regulation of foeto-placental steroidogenesis in Rhesus monkeys, 65. In : NOVY M. J., RESKO J. A., Foetal endocrinology. Acad. Press, New York. 
NUNEZ E., ENGELMANN F., BENASSAYAG C., JAYLE M. F., 1971. Identification et purification préliminaire de la foeto-protéine liant les oestrogènes dans le sérum de rats nouveau-nés. C.R. Acad. Sci. Paris, 273, 831-834.

ORTH D. N., NICHOLSON W. E., 1977. Different molecular forms of ACTH. Ann. N.Y. Acad. Sci., 297, $27-48$.

ORTH D.N., NICHOLSON W. E., SHAPIRO M., BYYNY R., 1970. Adrenocorticotropic hormone (ACTH) and melanocyte-stimulating hormone (MSH) production by a single cell. Program Endocr. Soc., 52nd Meet. St Louis, p. 140 (Abstr.).

ORTH D. N., NICHOLSON W. E., MITCHELL W. M., ISLAND D. P., SHAPIRO M., BYYNY R. L., 1973. ACTH and MSH production by a single-cloned mouse pituitary cell line. Endocrinology, 92, 385-393.

PAQUETTE T. L., HERBERT E., HINMAN M., 1979. Molecular weight forms of adrenocorticotropic hormone secreted by primary cultures of mouse anterior pituitary. Endocrinology, 104, 1211-1216.

PUOLAKKA J., KAUPPILA A., TUIMALA R., PAKARINEN A., 1982. Fetal adrenocorticotropic hormone and prolactin at delivery. Obstet. Gynecol., 60, 71-73.

RATTER S. J., LOWRY P. J., BESSER G. M., REES L. H., 1980. Chromatographic characterization of adrenocorticotrophin in human plasma. J. Endocrinol, 85, 359-369.

RAYMOURE W. J., KUHN R. W., 1983. A homologous radioimmunoassay for rat corticosteroidbinding globulin. Endocrinology, 112, 1091-1097.

ROEBUCK M. M., JONES C. T., HOLLAND D., SILMAN R., 1980. In vitro effects of high molecular weight forms of ACTH in the fetal sheep adrenal. Nature, 284, 616-618.

ROEBUCK M. M., JONES C. T., ROBINSON J. S., MITCHELL M. D., THORBURN G. D., 1984. ACTH control of steroid secretion from adrenal cells of the developing Rhesus monkey (Macaca mulatta). Acta endocrinol., 105, 545-551.

SCOTT A. P., LOWRY P. J., RATCLIFFE J. G., REES L. H., LANDON J., 1974a. Corticotrophinlike peptides in the rat pituitary. J. Endocrinol., 61, 355-367.

SCOTT A. P., LOWRY P. J., BENNETT H. P. J., MCMARTIN C., RATCLIFFE J. G., 1974b. Purification and characterization of porcine corticotrophin-like intermediate lobe peptide. J. Endocrinol., 61, 369-380.

SILMAN R. E., 1979. The stem hormone: changes in the adrenocorticotrophin and lipotrophin family tree of different species in foetal and adult life. J. Endocrinol, 80, 1P-2P.

SILMAN R. E., HOLLAND D., CHARD T., LOWRY P. J., HOPE J., ROBINSON J. S., THORBURN G. D., 1978. The ACTH « family tree » of the rhesus monkey; changes with development. Nature, 276, 526-528.

SILMAN R. E., HOLLAND D., CHARD T., LOWRY P. J., HOPE J., REES L. H., THOMAS A., NATHANIELSZ P., 1979. Adrenocorticotrophin-related peptides in adult and foetal sheep pituitary glands. J. Endocrinol., 81, 19-34.

VAN BAELEN H., VANDOREN G., DE MOOR P., 1977. Concentration of transcortin in the pregnant rat and its foetuses. J. Endocrinol., 75, 427-431.

WALSH S. W., NORMAN R. L., NOVY M. J., 1979. In utero regulation of Rhesus monkey fetal adrenals: effects of dexamethasone, adrenocorticotropin, thyrotropin-releasing hormone, prolactin, human chorionic gonadotropin, and $\alpha$-melanocyte-stimulating hormone on fetal and maternal plasma steroids. Endocrinology, 104, 1805-1813.

WINTERS A. J., OLIVER C., COLSTON C., MAC DONALD P. C., PORTER J. C., $1974 . \quad$ Plasma ACTH levels in the human fetus and neonate as related to age and parturition. $J$. clin. Endocrinol. Metab., 39, 269-273.

YALOW R. S., BERSON S. A., 1971. Size heterogeneity of immunoreactive human ACTH in plasma and in extracts of pituitary glands and ACTH-producing thymoma. Biochem. biophys. Res. Commun., 44, 439-445.

YALOW R. S., BERSON S. A., 1973. Characteristics of "big ACTH " in human plasma and pituitary extracts. J. clin. Endocrinol. Metab., 36, 415-423.

ZIMMERMAN A. E., KRAICER J., 1978. Multiple forms of ACTH biological activity in the pars intermedia of the rat adenohypophysis. Life Sci, 22, 1451-1462. 